\title{
(Ne)mogućnost eshatoloških implikacija na politiku
}

Ivan Glavinić*

ivan.glavinic@hotmail.com

https://orcid.org/0000-0001-5911-4203

Iva Mršić Felbar**

iva.mrsicfelbar@gmail.com

https://orcid.org/0000-0002-4402-9003 https://doi.org/10.31192/np.19.1.1

UDK: 27-175:32

Izvorni znanstveni rad / Original scientific paper

Primljeno: 28. listopada 2020.

Prihvaćeno: 14. prosinca 2020.

Članak istražuje složen odnos eshatologije i politike iz aspekta teološkog diskursa radi otkrivanja njihovih dodirnih točaka, a shodno tomu i implikacija koje eshatologija stavlja pred politiku. Nakana je članka da predstavi politiku kao interesno područje eshatologije i eshatologiju kao njezin kritički korektiv, te upozoriti na rizike i mogućnosti koje njihov suodnos ima. Uz pojmovna pojašnjenja prvotno se ističe karakteristično starozavjetno iskustvo eshatologiziranja povijesnih događaja, osobito proročko. Novozavjetna se pak eshatologija fokusira na Isusov odnos prema političkom životu. Konačno, problematizira se (ne)mogućnost govora o eshatološkim implikacijama na politiku, osobito kao zahtjev za političkim djelovanjem koje mora njegovati odnos prema prošlosti $i$ pravilno ga ugraditi u budućnost.

Ključne riječi: eshatologija, kraljevstvo Božje, nada, politika, prošlost.

\section{Uvod}

Eshatologija promišlja o odnosu čitavog čovjekovog života i njegove težnje za vječnošću te na temelju toga ističe zahtjeve za čovjekov život sada i ovdje. Tako možemo govoriti i o zahtjevima koje eshatologija stavlja pred čovjeka, ako je on zoon politikon - političko biće. Prilikom pojmovnog razjašnjenja pojmova eshatologija i politika, budući da se oba odnose na cjelokupnu stvarnost ljud-

\footnotetext{
* Ivan Glavinić, mag. theol., Osnovna škola Galdovo, Sisak, Brezovičkog odreda 1b, HR-44000 Sisak.

**Doc. dr. sc. Iva Mršić Felbar, Sveučilište u Zagrebu, Katolički bogoslovni fakultet, Vlaška 38, HR-10000 Zagreb.
} 
skoga života, bit će ključno ukazati na njihovu međusobnu povezanost, kao i istaknuti politiku kao interesno područje eshatologije.

Poveznicu eshatologije s politikom tražimo najprije u Starome zavjetu. Uvid u biblijsko iskustvo vjere, kao i njezina semantička obilježja, poslužit će nam za bolje razumijevanje vjere kao stvarnosti koja dinamizira cjelokupan život. U Novome zavjetu uočavamo da ni Isus nije živio odvojeno od političke situacije svoga vremena, te da su i prvi kršćani bili pozvani na svjedočanstvo vjere i na društvenom polju, unutar određenih političkih okvira.

Govor o eshatološkim implikacijama na politiku nije jednostavan niti je bez opasnosti. Eshatologija pred politiku stavlja smjernice, a ne gotova pravila. Cilj je ovoga rada pronaći smjernice kojima eshatologija može usmjeravati političko djelovanje, odnosno koje su mogućnosti njezinih implikacija na političko područje.

\section{Pojmovna objašnjenja}

Tema politike je itekako prisutna u socijalnom nauku Crkve, ${ }^{1}$ a u konačnici politiku želimo odrediti kao interesno područje eshatološkog promišljanja i djelovanja.

\subsection{Eshatologija i njezine zadaće u našem vremenu}

Etimološki gledano, grčki izrazi eshatos i logos ukazuju na to da je eshatologija nauk, ${ }^{2}$ odnosno teološka disciplina o posljednjim stvarima, o konačnoj sudbini čovječanstva i svijeta. Biblijski temelji eshatologije počivaju na starozavjetnoj povijesti nade te iskustvu Saveza s Bogom. ${ }^{3}$ Povijest nade poziva i obvezuje ljude da se u svome djelovanju oslone na Božju vjernost, da se sjećaju njegovih

${ }^{1}$ Usp. Stjepan BALOBAN (ur.), Kršćanstvo, Crkva i politika, Zagreb, Centar za promicanje socijalnog nauka Crkve - Glas Koncila, 1999, PAPINSKO VIJECE »IUSTITIA ET PAX«, Kompendij socijalnog nauka Crkve, Zagreb, Kršćanska sadašnjost - Centar za promicanje socijalnog nauka Crkve, 2005, (dalje: KSNC), Vladimir DUGALIĆ, Politička traganja Crkve u Hrvatskoj (1989.-2007.). Povijesno-teološka prosudba, Bogoslovska smotra, 77 (2007) 2, 483-539; Josip GRBAC, Političko-društveni vid supsidijarnosti. Teoretsko utemeljenje supsidijarnosti u društvenom i političkom životu, Bogoslovska smotra, 79 (2009) 1, 11-61; Silvija MIGLES, Jurica GREGURIĆ, Doprinos kršćana izgradnji političke kulture, Riječki teološki časopis, 49 (2017) 1, 81-123.

${ }^{2}$ Više o definiciji i naravi eshatologije kao nauka i dijela dogmatske teologije usp. Renzo LAVATORI, Gospodin će doći u slavi. Eshatologija u svjetlu Drugoga vatikanskog koncila, Zagreb, Kršćanska sadašnjost, 2011, 13-25; Candido POZO, Eshatologija, Sarajevo, Vrhbosanska katolička teologija, 1997, 37-46; Ladislav NEMET, Kršćanska eshatologija, Zagreb, Kršćanska sadašnjost, 2002, 7-25; Joseph RATZINGER, Eshatologija. Smrt i vječni život, Split, Verbum, 2016.

${ }^{3}$ Usp. Ladislav NEMET, Uvod u kršćansku eshatologiju, Obnovljeni život, 55 (2000) 2, 155-167, 161-162. 
djela u povijesti te da na temelju tog sjećanja grade odnos prema sadašnjosti i budućnosti. Proizlazi, stoga, da je za starozavjetnu eshatologiju važan motiv suradnje Boga i čovjeka.

Čovjek je unutar takve povijesti nade, kako primjećuje Moltmann, uvijek pozvan u položaj napetosti između iskustva i nadanja, što je za njega svojevrstan kreativni nemir. ${ }^{4}$ Ono što ovdje i sada možemo iskusiti kao ostvarenje nade ukazuje na Božju vjernost i znak je onoga konačnog čemu se nadamo, ali to ipak nije ono konačno i zato treba biti nadmašeno još čvršćom nadom, tj. nadom »protiv svake nade« $(\operatorname{Rim} 4,18) .{ }^{5}$ Nužno je, dakle, istražiti što takav događaj zahtijeva od nas da bismo imali udioništva u konačnom ispunjenju te nade.

\subsection{Politika i politička zajednica u socijalnom nauku Crkve}

»Politika je kolektivno i stalno djelovanje, ona je velik i smion pothvat čovječanstva, s uvijek novim i širim dimenzijama. Ona zadire istodobno u svakidašnji život i u sudbinu čovječanstva na svim razinama. ${ }^{6}$

Politika se može, u općenitom smislu, definirati kao javna djelatnost čija je svrha uređenje društva i odnosa u njemu, premda nije rijetkost da se politika »u najopćenitijim crtama određuje kao društveno ograničeno korištenje socijalne moći«. Iako povezana s vlasti i moći, u politici je prvotno ipak riječ o ljudskoj zajednici kao političkoj zajednici u kojoj se ostvaruje nastojanje za zajedničko, tj. opće dobro, pri čemu ono podrazumijeva uvjete u kojima ljudi mogu živjeti u miru i skladu te ostvariti svoj razvoj i usavršenje. ${ }^{8} \mathrm{~S}$ tim u vezi, socijalni nauk Crkve tumači da je cjelokupno političko djelovanje utemeljeno i usmjereno prema čovjeku kao osobi koja se istovremeno ostvaruje u odnosu prema Bogu i drugim ljudima. ${ }^{9}$ Čovjek je po naravi društveno biće, te proizlazi da politička zajednica »postoji da bi postigla cilj koji se inače ne bi mogao doseći: puniji rast svakoga svoga člana, pozvanih da stabilno surađuju da se ostvari opće dobro, uz

${ }^{4}$ Usp. Jürgen MOLTMANN, Teologija nade, Rijeka, Ex libris, 2008, 26-27.

${ }^{5}$ Usp. Moltmann, Teologija nade..., 21-27.

${ }^{6}$ POVJERENSTVO FRANCUSKIH BISKUPA ZA SOCIJALNA PITANJA, Za rehabilitaciju politike, Zagreb, Kršćanska sadašnjost, 1999, br. 3.

7 Ivan RIMAC, Politička kultura građana, u: Baloban (ur.), Kršćanstvo, Crkva i politika..., 105; usp. Robert E. GOODIN, Hans-Dieter KLINGEMANN, Political Science. The Discipline, u: isti (ur.), A New Handbook of Political Science, Oxford, Oxford University Press, 1996, 7.

${ }^{8}$ Usp. DRUGI VATIKANSKI SABOR, Gaudium et spes. Pastoralna konstitucija o Crkvi u suvremenom svijetu (17.XII.1965.), u: Dokumenti, Zagreb, Kršćanska sadašnjost, ${ }^{7} 2008$, br. 26, 74 (dalje: GS); HRVATSKA BISKUPSKA KONFERENCIJA, Katekizam Katoličke Crkve, Zagreb, Glas Koncila, 1994, br. 1906-1912 (dalje: KKC); Jacques MARITAIN, Cjeloviti humanizam, Zagreb, Kršćanska sadašnjost, 1989, 164-167; Jacques MARITAIN, Čovjek i država, Zagreb, Globus, 1992, 146149; Miljenko ŽAGAR, Kršćansko shvaćanje politike - odnos Crkve i države, Politička misao, 31 (1994) 4, 39-43, 39-40.

9 Usp. KSNC, br. 384; KKC, br. 1881-1912; GS, br. 25. 
potporu njihove naravne okrenutosti prema istinitom i prema dobru. $\aleph^{10}$ Drugi vatikanski sabor u pastoralnoj konstituciji o Crkvi u suvremenom svijetu, govoreći o politici, u prvi plan stavlja političku zajednicu, a tek potom političku vlast i njezin odnos prema zajednici. ${ }^{11}$ Sabor također odbacuje totalitarizam vlasti:

»Odbacuju se, međutim, svi oblici političkog uređenja koji su na snazi u nekim krajevima, a koji priječe građansku slobodu ili slobodu vjerovanja, umnažaju žrtve političkih strasti i zločinâ te okreću vršenje vlasti od zajedničkog dobra u korist neke stranke ili samih vlastodržaca. ${ }^{12}$

Koncil otvoreno govori o naravi i svrsi politike u njezinom subjektu - političkoj zajednici. Ne libi se također govoriti o potrebi odgoja za političko sudjelovanje i njegovanja zdravih unutarnjih osjećaja odgovornosti i pravednosti te o nastojanju prema općem dobru. ${ }^{13}$ Ukratko, potrebno je raditi na osposobljavanju i uključivanju u život političke zajednice.

\subsection{Politika kao interesno područje eshatologije}

Nada u uskrsnuće tijela i vječni život je temeljna kršćanska nada, čiji je najsnažniji temelj Isusovo uskrsnuće kao iskaz Božje vjernosti i ostvarenja obećanja (usp. 1 Kor 15,3-4; 1 Pt 1,3). S njim se ta nada započela ostvarivati; njegovo je uskrsnuće temelj naše nade, ali i poziv na preobrazbu života koja će jasno aktualizirati našu vjeru i nadu da se o posljednjem danu i na nama ostvari ono čemu se nadamo, a već se ostvarilo u Kristu (usp. Kol 3,1-4; 1 Sol 4,13 - 5,22; Tit 3,1-7). Zato je i moguće govoriti o nadi koja obvezuje sadašnjost, o eshatologiji koja se tiče sadašnjosti, a pritom ne daje mjesta pukom apsolutiziranju ove sadašnjosti kao takve. Kako Ratzinger ističe, uspoređujući platonsku misao i kršćansko viđenje odnosa kršćanske vjere i povijesti: »Ostajući u povijesti, mi ipak stalno živimo iznad povijesti, ali tako da ovo iznad ulazi u povijest kao izvorište i kao nada. « ${ }^{14}$ Konačno, možemo reći da vječni život, koji je središnja eshatološka kategorija, ne čini samo nešto što je onkraj, već bitno označava (dakako, ne posvema) naš život sad i ovdje.

Kršćanska nada, dakle, potiče čovjeka da se već sada svojim djelovanjem zalaže za ono što konačno iščekuje. Zadnje ispunjenje dolazi kao dar od Boga, a iščekivanje apsolutne budućnosti daje čovjeku poticaj za djelovanje (usp. $2 \mathrm{Pt}$ 3,11-12). Budućnost koju čovjek iščekuje povezana je s budućnošću koju čovjek sam stvara. Drugi vatikanski sabor ističe:

\footnotetext{
${ }^{10} \mathrm{KSNC}$, br. 384.

${ }^{11}$ Usp. GS, br. 74.

${ }^{12} \mathrm{GS}$, br. 73.

${ }^{13}$ Usp. GS, br. 75.

${ }^{14}$ Joseph RATZINGER, Teološki nauk o principima. Elementi fundamentalne teologije, Rijeka, Ex libris, 2010, 183.
} 
»Stoga, iako treba pomnjivo razlikovati ovozemni napredak od porasta Kristova kraljevstva, ipak je on od velike važnosti za Božje kraljevstvo jer može pridonijeti boljem uređenju ljudskog društva.:15

Plodonosno političko djelovanje, ukoliko je ono zaista rad na ostvarivanju općeg dobra, jest zalaganje na putu prema Kraljevstvu Božjem. Zato je politika kao ljudska djelatnost u stanovitom smislu interesno područje eshatologije. Budući da potpuno i konačno ostvarenje općeg dobra nije moguće na zemlji, nego tek u konačnoj budućnosti, usmjerenost političke zajednice prema općem dobru znak je stalne težnje ljudi prema konačnom dobru u vječnosti. Zato će istinsko političko djelovanje nužno imati dimenziju otvorenosti toj konačnoj budućnosti, što sprječava apsolutiziranje ovozemnog poretka i dobara. Eshatologija stoga politiku suočava sa zahtjevima te konačne budućnosti, dok joj je istodobno neprestan korektiv.

\section{Starozavjetno iskustvo eshatologiziranja povijesnih zbivanja}

Za starozavjetnu eshatologiju važno je iskustvo Boga spasitelja koji je s narodom sklopio Savez, ${ }^{16}$ koji ih poziva na vjernost Bogu u svakodnevici te ih usmjerava prema konačnoj budućnosti. Za temu politike i eshatologije važno je uočiti da Izraelovo iskustvo i iščekivanje počiva na povijesnim događajima koji često sadrže različita zbivanja, pa i ona politička - kao, na primjer, izlazak iz egipatskog ropstva: to je, gledano strogo povijesno, događaj i od političke važnosti, a ima velik utjecaj na vjeru izraelskog naroda. Židovi su narod koji je čuvao sjećanja na povijesna zbivanja i to shvaćao kao obvezu (usp. Pnz 4,9; 6,20-24) zbog toga što je povijest za njih zapravo mjesto očitovanja i ostvarivanja Božje volje i plana. ${ }^{17} \mathrm{~S}$ druge strane, Bog s čovjekom stvara povijest i traži njegovo udioništvo. Vjera je povijesno-egzistencijalni temelj starozavjetne eshatologije. Pojam vjerovanja u hebrejskoj Bibliji često je sadržan u glagolu 'mn (אמן), koji ima osnovno značenje biti čvrst. Od svih skupina glagola koji su semantički

\footnotetext{
${ }^{15}$ GS, br. 39; usp. KKC, br. 1820.

${ }^{16} \mathrm{O}$ specifičnostima starozavjetne eshatologije vidi više u: Adalbert REBIĆ, Biblijska eshatologija, Bogoslovska smotra, 73 (2003) 1, 72-73. Adalbert REBIĆ, Vjera u prekogrobni život u Starome zavjetu i u kasnim židovstvu. Starozavjetna (individualna) eshatologija, Bogoslovska smotra, 52 (1982) 3, 338-366; Rebić, Biblijska eshatologija, 71-100; Anđelo MALY, Neke crtice o starozavjetnoj eshatologiji, Bogoslovska smotra, 87 (2017) 2, 303-326; Ivan ŠPORČIĆ, 'Eshaton' u Starom zavjetu. Skica za starozavjetnu biblijsku eshatologiju, Riječki teološki časopis, 9 (1997) 1, 41-60.

${ }^{17}$ Usp. Edmund B. FRYDE, Historiography and Historical Methodology, u: The New Encyclopaedia Britannica. Macropedia, VIII, Chicago, Encyclopaedia Britannica, ${ }^{15} 1981,947-948$; B. C. SHAFER, History, u: New Catholic encyclopedia, VII, Washington, McGraw-Hill, 1967, 14-15.
} 
povezani s ovim temeljnim glagolom, nama je najzanimljivija skupina glagola nadati se i očekivati: ${ }^{18}$

"Semantičko obilježje ove skupine glagola daje sadržajima vjere usmjerenost prema budućnosti, jer i nada i očekivanje dolaze upravo iz budućnosti. (...) Oni izražavaju dimenziju vjere koja se odnosi na budućnost i pokazuju kako je vjera otvorena stvarnost, zapravo odnos prema Bogu koji nije bio samo u prošlosti, koji nije samo nazočan u sadašnjosti, nego koji će zacijelo doći i iz budućnosti.« ${ }^{19}$

Vjera obuhvaća cjelokupan ljudski život, odnosno tiče se osobne, ali i političke sfere. Starozavjetni proroci svojim su djelovanjem izraelskom narodu predali svijest o postojanju prošlosti, sadašnjosti i budućnosti te su pozivali na ispravan odnos prema vremenu koje povezuje Božja ljubav i naum spasenja koji se već očitovao i koji će se očitovati u budućnosti. ${ }^{20}$

U konkretnoj povijesti izraelskog naroda važan je bio odnos prema kraljevima. Iako se Božje djelovanje može očitovati i putem stranih vladara (usp. Iz 45,1-6), za Izrael je bila važna Davidova uloga, uz čiju se lozu veže i Božje obećanje postojanosti kraljevstva (usp. 2 Sam 7,8-16). Izraelski vladari često su bili kritizirani, osobito od strane prorokâ. Kralj je za Izrael time, zbog povijesnog iskustva, uvijek ostao samo kralj, ali se zato razvijala misao o idealnome kralju koji će doći i čije kraljevstvo nikada neće proći (usp. Dn 7,14) - jer će sâm Bog kraljevati. ${ }^{21}$ Upravo se u govoru o idealnome kralju očituje povezanost političke dimenzije života i eshatološkog iščekivanja: ono eshatološko - idealan kralj - je $u$ isto vrijeme i cilj iščekivanja i kritika postojećeg stanja, stanja na koje čovjek može sada utjecati i promijeniti ga. Budući, dakle, da je starozavjetni pojam vjere vezan uz konkretan život, zahtjevi koje budućnost (eshaton) stavlja pred sadašnjost imaju karakter načela koje mora biti uzeto u obzir u konkretnom životu, u konkretnoj političkoj situaciji.

\section{Novozavjetna eshatologija - Isus i politički život}

Novozavjetni tekstovi potiču na djelovanje da bismo bili »suradnici na kraljevstvu Božjem « (Kol 4,11), znajući pritom da ono nije naša zasluga, već za nj treba moliti Boga (usp. Mt 6,10.33) i primiti ga poput djeteta (usp. Lk 18,17).

Isus u svom propovijedanju naglašava darovanost Kraljevstva Božjega, čime želi dati do znanja da ono nije rezultat samo ljudskog rada, već plod Božje ljubavi (usp. Lk 12,32). To naglašava Gutiérrez, ističući da se samo u takvom razumijevanju Kraljevstva Božjega može »proniknuti u smisao aktivnog čovje-

\footnotetext{
${ }^{18}$ Cjelovitu analizu uporabe različitih oblika glagola 'mn vidi u: Lujić, Vjera u Boga..., 26-36; 6979.

${ }^{19}$ Isto, 33.

${ }^{20}$ Usp. isto, 93-94; Rebić, Biblijska eshatologija..., 75-76.

${ }^{21}$ Usp. Lujić, Vjera u Boga..., 380-383.
} 
kovog sudjelovanja u dolasku Kraljevstva «, ${ }^{22}$ čiji je temelj ljubav prema Bogu i bližnjemu, pa čak i prema neprijatelju ili progonitelju (usp. Mt 5,43-45). Uz to, Gutiérrez tvrdi da je oslobođenje koje Isus donosi cjelovito te, kao i njegova poruka o Kraljevstvu, namijenjeno svim ljudima (usp. Mk 16,15). Isus je tako u svom djelovanju usmjeren na temelj nepravde među ljudima - grijeh - ali pritom cjelokupno njegovo djelovanje nije ograničeno tek na duhovnu dimenziju čovjekova života. ${ }^{23}$ Njegovo djelovanje, navještaj Kraljevstva, poziv na obraćenje i vjerovanje evanđelju (usp. Mk 1,15) zadire u sve dimenzije života, jer je usmjereno upravo na čovjeka kao osobu.

Isus u naviještanju Kraljevstva Božjeg naglašava njegovu blizinu (usp. Mt 4,17; Mk 1,15) te se ne bavi politikom u uskom smislu te riječi, već traži obraćenje čovjeka pojedinca. ${ }^{24}$ Obraćenje i eshatologija, tj. pokora i djela milosrđa u ovome svijetu i iščekivanje budućeg svijeta u Isusovu navještaju Kraljevstva Božjeg usko su povezani. ${ }^{25}$ Jasno je, dakle, kako u Isusovom navještaju postoji svijest o blizini Kraljevstva Božjega, a istovremeno vrijedi ono još ne, što ostavlja mjesto čovjekovu djelovanju u svijetu. Navješćujući kraljevstvo nebesko, Isus ne zanemaruje posve političku dimenziju ljudskog života, ali svoje djelo među ljudima obavlja »imajući u vidu plodnije posljedice«. ${ }^{26}$ Isusov navještaj kraljevstva nebeskog u sebi sadrži navještaj pravednosti ${ }^{27}$ i mira, što je u punini ostvarivo tek u potpunom zajedništvu svih ljudi s Bogom. To je vidljivo i u činjenici da, kako Ratzinger navodi, Isus naviješta to Kraljevstvo posebno siromasima ${ }^{28}$ Isus naviješta kraljevstvo nebesko gladnima i žednima pravednosti, progonjenima, mirotvorcima (usp. Mt 5,1-12). Gutiérrez upravo u tome vidi povezanost političke dimenzije ljudskog života s Isusovim djelovanjem jer

»Isusovo svjedočenje i poruka dobivaju tu političku dimenziju upravo zbog temeljitosti svog spasenjskog karaktera; propovijedati sveopću ljubav Očevu neizbježno je protivljenje svakoj nepravdi, povlasticama, tlačenju ili uskom nacionalizmu. $\ll^{29}$

Konačno, takav stav i navještaj stajao ga je vlastita života (gledajući strogo povijesno) i doveo do smrti koja je po načinu izvršenja bila politička.

Budućnost kojoj se čovjek nada u vječnosti i budućnost koju sad stvara nisu suprotstavljene, već su, naprotiv, povezane. Kršćanska nada potiče čovjeka da već sada živi prema onome što očekuje kod Boga, po uzoru na Isusa koji je kao

\footnotetext{
${ }^{22}$ Gutiérrez, Teologija oslobođenja..., 257.

${ }^{23}$ Usp. isto, 257; 263.

${ }^{24}$ Usp. isto, 260.

${ }^{25}$ Usp. Ratzinger, Eshatologija..., 39-40.

${ }^{26}$ Gutiérrez, Teologija oslobođenja..., 263.

${ }^{27}$ Usp. isto, 264.

${ }^{28}$ Usp. Ratzinger, Eshatologija..., 39.

${ }^{29}$ Gutiérrez, Teologija oslobođenja..., 264.
} 
Bog s nama pripremao ljude za to Kraljevstvo. ${ }^{30}$ Nasljedovati Isusa u svakodnevnom životu, u usmjerenosti prema vječnosti, znači mijenjati sebe i društvene odnose u skladu s evanđeljem, tj. kao i on, tražiti »novog čovjeka u kvalitativno drukčijem društvu «, ${ }^{31}$ što za sobom povlači posljedice na području političkog djelovanja kršćanina. Čovjek svojim radom ne uspostavlja konačno kraljevstvo nebesko, budući da je ono dar, ali on treba težiti njemu kroz svoj život vršenjem prava, promicanjem pravednosti, odbacivanjem grijeha i djelima ljubavi. ${ }^{32}$

\section{4. (Ne)mogućnost govora o eshatološkim implikacijama na politiku}

Eshatologija ne odbacuje i ne zanemaruje ovu povijest i ovaj svijet, iako kršćanska nada prvotno iščekuje ono buduće. Ta budućnost se nudi čovjeku već ovdje i poziva čovjeka da živi sub specie aeternitatis. ${ }^{33}$ Kršćanska nada je već ostvarena u Isusu Kristu (usp. 1 Tim 1,1) čiji ponovni dolazak još iščekujemo. Budući da je čovjek biće i ovog neba i ove zemlje, kršćanska nada, želi li se jasno i plodonosno navijestiti, treba se očitovati u konkretnim situacijama, pa tako i u konkretnom političkom djelovanju.

\subsection{Eshatološke implikacije na politiku u nekim konkretnim društvenim prilikama}

Kršćanska eshatologija relevantna je za politiku, ali svoju relevantnost očituje posrednim putem. Tako, naime, tvrdi Ratzinger kada ističe:

»Poruka Božjega kraljevstva ima značenje za politiku, ali ne putu koji vodi preko eshatologije, nego na putu koji vodi preko političke etike. Pitanje kršćanski odgovorne politike ne pripada eshatologiji nego moralnoj teologiji i na ovom putu poruka o kraljevstvu Božjemu ima nešto jako važno reći politici.« ${ }^{34}$

Eshatologija, dakle, putem moralne teologije utječe na političko djelovanje, pružajući tako temeljne smjernice za političko djelovanje. Neke od tih smjernica su: prvenstvo dostojanstva ljudske osobe i nepovredivost ljudskog života, razumijevanje vlasti kao službe, osobito službe u istini nasuprot neprihvatljivog

\footnotetext{
${ }^{30}$ Usp. Mijo ŠKVORC, Isus - Spasitelj. Životni put i Tajna osobe, Zagreb, Filozofsko-teološki institut Družbe Isusove, 1998, 641-642.

${ }^{31}$ Gutiérrez, Teologija oslobođenja..., 263-264.

${ }^{32}$ Usp. Ivica RAGUŽ, Papa Benedikt XVI. o Crkvi, državi i politici, Bogoslovska smotra, 77 (2007) 2, 419-435, 426; Joseph RATZINGER, Wendezeit für Europa? Diagnosen und Prognosen zur Lage von Kirche und Welt, Einsiedeln - Freiburg, Johannes-Verlag, ${ }^{32} 2005,56$.

${ }^{33}$ Usp. Ivan DEVČIĆ, Nada i kriza novovjekovnih utopija, Riječki teološki časopis, 5 (1997) 1, 13 $39,36$.

${ }^{34}$ Ratzinger, Eshatologija..., 67.
} 
etičkog pluralizma, zauzimanje za mir, siromašne i pravednu razdiobu dobara u svijetu, ali i mnoge druge. ${ }^{35}$ Iako su ova usmjerenja mnogobrojna, istaknut ćemo dva trajna zahtjeva. Naime, eshatologija utječe na politiku barem na dvije razine: na razini pojedinca i na razini društvene političke djelatnosti. Na prvoj razini riječ je o očitovanju nade kao zahtjeva za političkim angažmanom, odnosno djelovanjem pojedinca, dok je na drugoj razini riječ o pozivu na odgovoran odnos prema prošlosti i čuvanju spomena.

\subsubsection{Eshatološki dar zahtijeva političko djelovanje}

Kršćanska eshatologija nalazi najjasniju sliku povezanosti punine Kraljevstva Božjeg s ovozemaljskim nastojanjima u Novome zavjetu. Isusove riječi koje donosi, primjerice, Matejevo evanđelje jasno stavljaju te dvije stvarnosti u vezu koja je društvenog karaktera, tj. koja se očituje u odnosima među ljudima: »Pazite da svoje pravednosti ne činite pred ljudima da vas oni vide. Inače, nema vam plaće $u$ vašeg Oca koji je na nebesima« (Mt 6,1); »Ne sudite da ne budete suđeni!« (Mt 7,1); »Tko napoji jednoga od ovih najmanjih samo čašom hladne vode zato što je moj učenik, zaista, kažem vam, neće mu propasti plaća« (Mt $10,42)$.

Vječni život, eshaton, koji je u svojoj bîti zajedništvo s Bogom, čovjeku je poziv i cilj kojemu treba težiti, istovremeno ostajući Božjim darom koji zahtijeva od čovjeka da ga prihvati živeći svoj ovozemaljski život u perspektivi konačnog ispunjenja nade i Kraljevstva Božjeg. ${ }^{36}$ To je naglašeno i u Svetom pismu. Čovjek ne može zanemariti ovaj život i svoje dužnosti u njemu radi onoga budućeg; iščekivanje budućeg potiče i usmjerava čovjekovo djelovanje u ovome svijetu:

»Iako se ta dva poretka [duhovni i vremeniti, op. a.] razlikuju, oni su u jednom Božjem planu tako povezani, da sâm Bog hoće sav svijet učiniti u Kristu novim stvorenjem, početno ovdje na zemlji, a potpuno u posljednji dan. « ${ }^{37}$

Nada u konačno ostvarenje Kraljevstva Božjeg obvezuje čovjeka da ga već sada naviješta i svojim djelovanjem za dobro čovječanstva usmjerava svijet prema tome cilju. ${ }^{38}$ Stoga je eshatologija relevantna ne samo za tu, još uvijek

\footnotetext{
${ }^{35}$ Nemali broj teologa, ali i crkvenih dokumenata donosi popis tih smjernica, iz kojih i mi ovdje crpimo nadahnuće i na temelju kojih ih ukratko navodimo. Bitno je istaknuti da se sve one odnose općenito na sudjelovanje kršćana u politici, te je stoga zahtjeve eshatologije naspram politike moguće iščitavati jedino kao implicitno sadržane (usp. Povjerenstvo francuskih biskupa za socijalna pitanja, Za rehabilitaciju politike...; KSNC; GS; Kongregacija za nauk vjere, Doktrinalna nota o nekim pitanjima veznim uz sudjelovanje katolika u političkom životu...; Maritain, Cjeloviti humanizam..., 316-364; Gerhard Ludwig MÜLLER, Siromaštvo. Izazov za vjeru, Zagreb, Kršćanska sadašnjost, 2015, 118-146 i dr.).

${ }^{36}$ Usp. PAPINSKA BIBLIJSKA KOMISIJA, Biblija $i$ moral. Biblijski korijeni kršćanskoga djelovanja, Zagreb, Kršćanska sadašnjost, 2010, br. 85-91.

${ }^{37}$ DRUGI VATIKANSKI SABOR, Apostolicam actuositatem. Dekret o apostolatu laika (18. XI.1965.), u: Dokumenti, Zagreb, Kršćanska sadašnjost, ${ }^{72008}$, br. 5.

${ }^{38}$ Usp. Povjerenstvo francuskih biskupa za socijalna pitanja, Za rehabilitaciju politike..., br. 15.
} 
iščekivanu, konačnu budućnost, već i za ovu sadašnjost s Bogom. Bog i njegovo Kraljevstvo, dakle, nisu posve odijeljeni od ovoga svijeta i ove povijesti, kao da nemaju ništa s njom, pa se stoga ni budućnosti, u punini života s Bogom, ne mogu gledati kao nešto posve odijeljeno od ovoga svijeta i vremena. Ta budućnost je sâm Bog - koji je temelj i izvor čovjekove nade. Naposljetku, on sam je dio te povijesti.

Nada koju nosi kršćanska vjera ima, dakle, ljudsku i društvenu dimenziju, zbog čega politika postaje područje za kršćansko djelovanje, kako nam je to Isus pokazao svojim djelovanjem u društvu. Konačno, tim političkim djelovanjem čovjek sudjeluje u Božjem planu ostvarenja njegova Kraljevstva, iako se punina Kraljevstva tek ima dogoditi kao Božji dar. ${ }^{39}$ Politika, naime, ne otkupljuje čovjeka, ${ }^{40}$ ali ipak ostaje važna činjenica:

»Udaljuju se od istine oni koji, znajući da ovdje nemamo stalnoga grada, nego da tragamo za budućim, misle kako zbog toga mogu zanemariti svoje zemaljske dužnosti. Pritom zaboravljaju da ih sama vjera još više obvezuje na njihovo ispunjavanje u skladu s pozivom kojim je svatko pozvan. (...) Neka se kršćani pače raduju što, slijedeći primjer Krista, koji je obavljao posao zanatlije, mogu obavljati sve svoje zemaljske djelatnosti tako da ljudska, kućna, stručna, znanstvena ili tehnička nastojanja ujedinjuju u životnu sintezu s religioznim dobrima, pod čijim se uzvišenim vodstvom sve usklađuje na slavu Božju. «11

Kršćanska nada, tražeći ovostrano zalaganje, čovjeka oslobađa za plodno djelovanje i upravlja ga konačnom dobru koje je dobro sviju - opće dobro. Važno je omogućiti sudjelovanje u politici, prema mjeri darova i sposobnosti pojedinca. Kršćanska je nada neprestan poziv na političko djelovanje te istovremeno korektiv same politike. Političko djelovanje samo po sebi ne ostvaruje konačno Kraljevstvo Božje na zemlji, ali ga pomaže činiti prisutnim, tj. prepoznati kada se brine za pravednost i mir u ovome svijetu.

\subsubsection{Političko djelovanje i odnos prema prošlosti}

Naše vrijeme, ako je vjerovati Metzu, moglo bi se lako označiti kao vrijeme u kojemu se njeguje zaborav.$^{42}$ Stoga je sjećanje važno i ono nije samo kategorija svojstvena religiji, nego je općeljudska kategorija. Sâm povijesni proces ima, kako Berdjajev primjećuje, dvije karakteristike: on čuva, ali istovremeno i raskida s prošlošću i upravo kao takav povijesni proces izrađuje povijest: sadašnjost

\footnotetext{
${ }^{39}$ Usp. isto, br. 35-36.

${ }^{40} \mathrm{O}$ tematici odnosa vremenitog oslobođenja i punine slobode vidi: SVETI ZBOR ZA NAUK VJERE, Uputa o nekim aspektima teologije oslobođenja, Zagreb, Kršćanska sadašnjost, 1984; ZBOR ZA NAUK VJERE, Naputak o kršćanskoj slobodi i oslobodenju, Zagreb, Kršćanska sadašnjost, 1986.

${ }^{41}$ GS, br. 43; Usp. Kongregacija za nauk vjere, Doktrinalna nota o nekim pitanjima veznim uz sudjelovanje katolika u političkom životu, br. 9; IVAN PAVAO II., Christifideles laici, Zagreb, Kršćanska sadašnjost, 1990, br. 59.

${ }^{42}$ Usp. Johann Baptist METZ, Politička teologija, Zagreb, Kršćanska sadašnjost, 2004, 224-230.
} 
sama za sebe nije potpuna povijest, tj. nije potpuno vrijeme, kao ni budućnost sama za sebe. Stoga je pamćenje važno, jer ono povezuje vrijeme, čini da prošlo prožima sadašnje i bude prisutno kroz pamćenje, spomen. ${ }^{43}$ Zato možemo reći da je pamćenje, tj. sjećanje, jedna od najvažnijih zadaća i istodobno trajan zahtjev kršćanske nade spram politike.

U Svetom pismu lako ćemo uočiti tu vezu: temelj nade i vjere u Starom zavjetu jest iskustvo Božjeg saveza, njegovih obećanja i djela spasenja, čija se aktualizacija, osim u bogoslužju, mora događati i u konkretnom životu (usp. Ps 50,23; Jr 29,4-11). I u Novome zavjetu, osobito u poslanicama, nailazimo na vezu prošlost - sadašnjost - budućnost (usp. 1 Kor 10,1-13; Heb 10,32 - 13,21). I u ranokršćanskom iskustvu za plodonosan rad za dobro zajednice važan je spomen, ali spomen koji nije sam sebi svrha, već je prožet vjerom u Boga i učvršćuje nadu koja usmjerava kršćaninov život (usp. Tit 2,11 - 3,3).

Dakle, političko djelovanje koje nema potrebu za spomenom, koje je zaborav, koje ne drži vezu s prošlošću - ostaje neutemeljeno. Štoviše, politika, ako ne drži do sjećanja, dokida nadu, jer dokida njezine zaloge i tako gubi vezu s budućnošću kojoj su ljudi po nadi usmjereni. Eshatologija upravo po nadi obavlja svoj zahtjev spram politike. Po nužnosti nade za ljudsku egzistenciju ona utječe na političko djelovanje. To djelovanje, ukoliko želi zaista biti djelovanje za opće dobro, mora uvijek aktualizirati zaloge nade, čuvajući spomen prošlosti, te tako usmjeravati društvo prema konačnom cilju.

Činjenice povijesti, kako Moltmann primjećuje, nisu dovršeni proces:

»Valja ih smatrati postajama na putu i momentima u procesu koji se dalje razvija. Stoga događaji kojih se na taj način 〈povijesno〉 sjećamo još uvijek ne sadrže svoju posljednju istinu u sebi samima, nego je dobivaju tek po obećanom i očekivanom Božjem obećanju. (...) Tako doživljeni događaji «moraju〉 se prenositi, jer u njima je viđeno ono što određuje i buduće generacije. ${ }^{44}$

Odgovoran odnos prema povijesti će unutar političkog djelovanja zahtijevati uvažavanje slobode istraživanja povijesti i uzdržavanje od ideološkog tumačenja povijesti. No, ostaje činjenica da će se na konkretnom području to raznoliko očitovati, već prema okolnostima svake nove sadašnjosti.

\subsection{Zaključno o konkretnim zahtjevima eshatologije spram politike}

Činjenica je da veza između eshatologije i politike ima i svoje rizike i svoje mogućnosti. Savršen društveni poredak i konačno dobro, naime, ne mogu se ostvariti u ovome svijetu, te stoga nastojanja da se ipak ostvare na ovome svijetu jesu udaljavanje od savršenosti i vode u nepravdu. S druge strane, sigurno je da kršćanska vjera ne poznaje radikalnu odijeljenost onostranosti i ovostranosti.

\footnotetext{
${ }^{43}$ Usp. Nikolaj BERDJAJEV, Smisao povijesti, Split, Verbum, 2005, 70-71.

${ }^{44}$ Moltmann, Teologija nade..., 115.
} 
Iščekivanje eshatološkog ostvarenja Kraljevstva Božjeg i povijesna nastojanja ljudi međusobno su povezani. Budući da Kraljevstvo Božje označuje dobro za sve, ono nužno uključuje poziv na djelovanje, pa tako i političko djelovanje s određenim zahtjevima.

Različite vrste uređenja vlasti, raznolikost političkih opcija, jedinstvenost svakog čovjeka te, u konačnici, jedinstvenost darova svakog pojedinca onemogućuju eshatologiji određivanje konkretnih pravila djelovanja politici. Premda ne pruža obrasce djelovanja u politici, kršćanska nada u sebi sadrži »etičke i duhovne putokaze koje možemo podijeliti s mnogim našim suvremenicima «, ${ }^{45}$ tj. smjernice za političko djelovanje koje su usmjerene općem dobru. Iako se može izvesti nemali broj tih smjernica, istaknuli smo dva važna zahtjeva koja eshatologija stavlja pred pojedinca, ako je političko biće, kao i pred samu politiku. Ti zahtjevi se mogu označiti kao poziv na uključivanje u političko djelovanje, te kao poziv na odgovoran odnos prema prošlosti i na čuvanje sjećanja. Potonji proizlazi iz unutarnje povezanosti vremena, iz prožimanja prvenstveno povijesti i budućnosti, ali i iz same ontologije nade. Uključivanje u političko djelovanje, osim iz naravi nade, proizlazi iz evanđeoskog poziva na plodnu zauzetost u društvenim odnosima te iz same naravi Kraljevstva kao dara kojemu se nadamo.

\section{Zaključak}

Isusovo uskrsnuće i oslobođenje od grijeha najjači su temelj kršćanske nade jer su savršen iskaz Božje vjernosti i ostvarenja obećanja. Zato možemo govoriti o nadi koja obvezuje našu sadašnjost, o eshatologiji koja suočava sadašnjost sa zahtjevima budućnosti. Kršćanska nada potiče na djelatno zalaganje za ono što konačno iščekujemo, premda uvijek u otvorenosti Božjem djelovanju. Iščekivana budućnost time je povezana s budućnošću koju čovjek sam stvara. To je sadržano i u tvrdnji Drugog vatikanskog sabora:

»Iako treba pomnjivo razlikovati ovozemni napredak od porasta Kristova kraljevstva, ipak je on od velike važnosti za Božje kraljevstvo jer može pridonijeti boljem uređenju ljudskog društva.« ${ }^{46}$

Usmjerenost čovjeka i političke zajednice prema općem dobru ovdje na zemlji je iskaz težnje ljudi prema eshatološkom dobru i konačnom Kraljevstvu Božjem. Eshatologija tako politiku suočava sa zahtjevima te konačne budućnosti i istodobno je njezin kritički korektiv.

Za proroke budućnost ima snagu u sadašnjosti po prethodnom Božjem obećanju spasenja. To obećanje spasenja zahtijeva konkretan pristanak u nekom

\footnotetext{
${ }^{45}$ Povjerenstvo francuskih biskupa za socijalna pitanja, Za rehabilitaciju politike.., br. 12.

${ }^{46} \mathrm{GS}$, br. 39 .
} 
trenutku, pa i onom političkom, i zato je Božja budućnost eshatološka kritika sadašnjosti. Isus nam je u tom smislu dao primjer djelovanja: umrijevši kao navodni politički pobunjenik, pokazao nam je koliki utjecaj politika ima na ovu povijest, a koliko, s druge strane, njegovo Kraljevstvo nadilazi politiku.

Veza između eshatologije i politike, ako nije trezveno održavana, može odvesti i u teološka i u politička zastranjenja. No, ono eshatološko Kraljevstva Božjeg i čovjekova povijesna nastojanja na putu prema njemu - međusobno su povezani. Iščekivanje konačnog Božjega kraljevstva ima značenje za politiku, ali tek, kako smo vidjeli, putem političke etike, odnosno moralne teologije. Budući da Kraljevstvo Božje označuje konačno dobro čovjeka, ono kršćanina poziva na političko djelovanje i jačanje nade, što je moguće samo ako se on istodobno odgovorno odnosi prema prošlosti. Bez tog odgovornog odnosa prema prošlosti, gube se čvrsti zalozi nade, te tako slabi i unutarnja veza vremena, što može negativno utjecati na pogled na sadašnjost i otežati pogled u budućnost.

Eshatologija stavlja pred politiku i pojedinca u njoj dva zahtjeva: obvezu čuvanja sjećanja te uključivanje u političko djelovanje - bilo u užem ili u širem smislu. Prvi proizlazi iz unutarnje povezanosti vremena, iz njegove dinamike koja očituje međusobno neraskidivo prožimanje prošlosti, sadašnjosti i budućnosti, ali i iz same srži nade. Također je nužno istaknuti da kršćanska nada teži aktualizaciji upravo pomoću sjećanja: spomen u sadašnjosti obnavlja ono oslobađajuće iskustvo nade usmjereno konačnom spasenju. Drugi zahtjev - onaj za uključivanjem u političko djelovanje - proizlazi pak, osim iz same naravi nade, i iz evanđeoskog poziva na plodnu zauzetost za ostvarenje boljih društvenih odnosa te iz naravi Kraljevstva kao dara kojemu se nadamo. Kraljevstvo Božje, kako smo istaknuli, zahtijeva djelatno prihvaćanje putem izgradnje drukčijih, boljih odnosa u društvu, pa i putem političkog djelovanja, a upravo ti novi odnosi u društvu već sada čine Kraljevstvo Božje, koje uvijek ostaje Božji dar, otajstveno prisutnim u svijetu. 


\section{Ivan Glavinić" - Iva Mršić Felbar"** \\ (Im)possibility of Eschatological Implications to Politics \\ Summary}

The paper researches the complex relation between Eschatology and Politics from the theological point of view by revealing their mutual points, and along with that aims to present the eschatological implications that are being put to Politics. The intention of this paper is to represent the Politics as interest field of Eschatology and also Eschatology as its critical corrective by warning to the risks and possibilities its relationship has to offer.

Aside to notional explanations the paper firstly emphasizes the characteristic Old testament experience from historical events that were interpreted in the eschatological key, especially with the role of the prophets. New testament Eschatology is focused here on Jesus' relation to political life. Finally, the paper reflects the (im)possibility to speak of the eschatological implications to Politics in some concrete social issues, especially as a notion for political action that must nourish the relation towards past and correctly embed it to the future.

Key words: eschatology, history, hope, kingdom of God, politics.

(na engl. prev. Iva Mršić Felbar)

\footnotetext{
* Ivan Glavinić, MA, Elementary School Galdovo, Sisak; Address: Brezovičkog odreda 1b, HR44000 Sisak, Croatia; E-mail: ivan.glavinic@hotmail.com.

**Iva Mršić Felbar, PhD, Assis. Prof., University of Zagreb, Catholic Faculty of Theology; Address: Vlaška 38, HR-10000 Zagreb, Croatia; E-mail: iva.mrsicfelbar@gmail.com.
} 